(C) Middle East Institute. This article is for personal research only and may not be copied or distributed in any form without the permission of The Middle East Journal.

\title{
Good for the Shah, Banned for the Mullahs: The West and Iran's Quest for Nuclear Power
}

\author{
Mustafa Kibaroglu
}

\begin{abstract}
Iran's nuclear program has become a highly controversial issue in international politics since the August 2002 unveiling of the secretly built uranium enrichment facility in Natanz and the heavy-water production plant in Arak. American officials and experts assert that Iran has secret plans to use its nuclear capabilities to develop nuclear weapons. Iranian officials, however, deny such allegations and claim that they will use their capabilities exclusively for peaceful purposes. Notwithstanding the official rhetoric, some Iranian scholars, intellectuals, and even bureaucrats argue that Iran should seriously consider developing nuclear weapons given that they have the necessary skills and capabilities as well as the reasons to do so. The clerical leaders have supposedly not yet decided about weaponizing Iran's nuclear capability. However, the ever-increasing size of Iran's existing nuclear infrastructure, and the achievements of Iranian scientists, who claim to have developed indigenous capabilities, may very well elevate Iran to the status of a nuclear power, even a de facto nuclear-weapons state.
\end{abstract}

$\mathrm{T}_{\mathrm{t}}$ he prevailing view among Iranian bureaucrats and scientists who have been for many years involved in nuclear projects and others who are well entrenched in the state structure is that Iran should definitely have nuclear technology and even weapons. Those who are seemingly against nuclear weapons development maintain that the the international situation is not suitable, and they suggest waiting. Statements made by Americans and Israelis about a military strike on Iran's nuclear facilities strengthen the views of those who endorse nuclear weapons development; however, weaponization of Iran's capabilities will depend on the political calculus of the leadership. ${ }^{1}$ Against this background, the aim of this article is to discuss in detail the implications of Iran's

Dr. Mustafa Kibaroglu teaches courses on proliferation of weapons of mass destruction, arms control, and disarmament in the Department of International Relations at Bilkent University in Ankara (kibar@bilkent.edu.tr). This paper was written during the author's sabbatical fellowship at the Belfer Center for Science and International Affairs in the Kennedy School of Government at Harvard University in the 2004-2005 academic year.

1. These views were expressed by Dr. Kayhan Barzegar, Assistant Professor at Islamic Azad University, Science and Research Campus, and an Associate Fellow at the Tehran-based Center for Strategic Studies, in conversations on the sidelines of two conferences convened in Tehran in the first week of March 2005. The first was the "Persian Gulf Security Conference" organized by the Iranian Institute for Political and International Studies, on March 1-2, 2005; the second was "The International Conference on Nuclear Technologies and Sustainable Development" organized by The Center for Strategic Studies, on March 5-6, 2005.

MIDDLEEAST JOURNAL ^ VOLUME 60, NO. 2, SPRING 2006 
nuclear capabilities for regional and international peace and stability.

Let us begin with a reminder of the crisis that erupted in 2002 between Iran and the United States (US) over Iran's nuclear capabilities and intentions. An overview of the crisis, which also involved the International Atomic Energy Agency (IAEA) and the European Union (EU) will highlight the positions of these actors.

Iran's desire to develop a full-fledged nuclear fuel cycle is not new. Since the mid-1970s, under the leadership of both the Shah and the mullahs, Iran has been developing considerable technological infrastructure and accumulating valuable scientific expertise in the nuclear field. Therefore, Iran's strategic relations with the US and the leading European nations such as France and (West) Germany in the 1960s and 1970s will be discussed with special emphasis on their nuclear cooperation. The achievements of Iran in the nuclear field under the Shah came to a temporary halt with the dramatic changes of the Islamic Revolution in 1979.

Despite the deterioration of its relations with the West after the Islamic Revolution, Iran soon resumed its efforts to finish its nuclear projects, but there were serious difficulties because of the US policy of denying the transfer of nuclear technology and material. Russia and China entered the picture and helped Iran develop significant nuclear capabilities. ${ }^{2}$ This article will examine closely the ups and downs in Iran's efforts to advance in the field both technologically and scientifically.

Building on this, a discussion will follow about whether Iran intends to develop nuclear weapons with the capabilities that it has now or will acquire in the future. To have a better idea about Iran's motivations and how long it may take it to build nuclear weapons, this article will present the views of Iranian scholars, scientists, bureaucrats, and intellectuals who are involved in the nuclear projects.

Given Iran's probable desire to acquire nuclear weapons, this article will discuss the possible consequences of the policy options that are available to the US in its effort to prevent Iran from realizing its ambitions. A discussion will follow about whether other states in the region, such as Iraq, Saudi Arabia, Egypt, Syria, and Turkey will seek nuclear weapons to counter Iran's nuclear capabilities.

The central theme in this article suggests that the development of nuclear weapons by Iran will not only exacerbate tensions in the Middle East, but will also constitute a serious blow to the nuclear non-proliferation regime. Thus, the concluding remarks will discuss what can be done to find a solution to the crisis between Iran and the US, both of whom have maintained their positions regarding the major points of disagreements since late 2002 .

2. For a detailed documentation of Iran's nuclear facilities see a compilation by Andrew Koch and Jeanette Wolf, Iran's Nuclear Facilities: A Profile (Monterey, CA.: Center for Nonproliferation Studies, 1998). For more up-to-date information including satellite imagery of some of the facilities in Iran, visit http://www.globalsecurity.org. 


\section{REVELATIONS OF IRAN'S SECRET NUCLEAR FACILITIES AND THE CRISIS}

In a press conference in Washington DC on August 14, 2002, the US Representative Office of the National Council of Resistance of Iran revealed the top secret nuclear projects of Iran, namely the uranium enrichment facility in Natanz, and the heavy water production facility in Arak. ${ }^{3}$ The discovery of these plants, which require demanding technology and sophisticated expertise, suggested that Iran had made considerable progress on these two different routes to nuclear weapons throughout the 1990s, despite US sanctions.

\section{THE REACTION OF THE US}

Revelations about Iran's degree of sophistication and level of technological expertise, as well as the clandestine nature of the work done in these fields caused strong reactions in the US. The US made it clear that Iran's effort to build undeclared uranium enrichment facilities in Natanz was a clear indication of the secret intentions of that country to develop nuclear weapons, and thus a violation of both the spirit and the letter of Article II of the Non-Proliferation Treaty (NPT). ${ }^{4}$ Frequently, Americans have argued that Iran should not be entitled to exercise its rights under Article IV of the same Treaty to develop nuclear technology. ${ }^{5}$ Accordingly, the US requested Iran to give up its uranium enrichment activities; the US further wanted Iran's nuclear dossier at the Board of Governors of the IAEA to be transferred to the United Nations Security Council (UNSC) so that punitive action could be taken for its violations of the NPT obligations.

3. For coverage of the press conference, see Global Security's website: http://www.globalsecurity.org/ wmd/world/iran/natanz.htm.

4. Article II of the NPT reads as follows: "Each non-nuclear-weapon State Party to the Treaty undertakes not to receive the transfer from any transferor whatsoever of nuclear weapons or other nuclear explosive devices or of control over such weapons or explosive devices directly, or indirectly; not to manufacture or otherwise acquire nuclear weapons or other nuclear explosive devices; and not to seek or receive any assistance in the manufacture of nuclear weapons or other nuclear explosive devices."

5. Article IV of the NPT reads as follows: Paragraph 1. "Nothing in this Treaty shall be interpreted as affecting the inalienable right of all the Parties to the Treaty to develop research, production and use of nuclear energy for peaceful purposes without discrimination and in conformity with articles I and II of this Treaty."

Paragraph 2. "All the Parties to the Treaty undertake to facilitate, and have the right to participate in, the fullest possible exchange of equipment, materials and scientific and technological information for the peaceful uses of nuclear energy. Parties to the Treaty in a position to do so shall also cooperate in contributing alone or together with other States or international organizations to the further development of the applications of nuclear energy for peaceful purposes, especially in the territories of non-nuclearweapon States Party to the Treaty, with due consideration for the needs of the developing areas of the world." 


\section{IRAN's RESPONSE To The ACCUSATIONS}

Iranian authorities denied that they had secret plans to build nuclear weapons or that they had violated their NPT obligations. They acknowledged that they failed to report some of the progress in their nuclear program to the IAEA in a timely fashion. In private conversations, Iranian officials gave lengthy explanations of how internal bureaucratic dynamics in Iran have played a role in the failure to provide the IAEA with the design information and all other related data about the facility. ${ }^{6}$ However, some of them also said that "they had no other alternative but to build the facility secretly" arguing that "if they had notified the IAEA that they were building a uranium enrichment facility, the US would have definitely prevented them from finalizing the project." "

Iran invokes Article IV of the Treaty in defending its various nuclear projects including enrichment and reprocessing. ${ }^{8}$ Iranian authorities argue that nothing in the Treaty should affect the inalienable right of the member states to develop nuclear energy for peaceful purposes, and they flatly reject the US request to stop enriching uranium. Iranian authorities also argue that the IAEA has certified that not notifying the Agency about Natanz was just a "failure" rather than a "violation" of Iran's safeguards obligations. Asserting that they were cleared of the allegation of violation, Iranian officials indicate that they expect to be treated like other non-nuclear weapons states that are party to the NPT; they point out that Argentina, Brazil, Japan, and Belgium have enrichment and reprocessing capabilities, but are not subject to accusations of developing nuclear weapons. ${ }^{9}$

\section{THE RoLE OF THE IAEA}

The IAEA played a crucial role in fostering discussion about Iran's nuclear program; they called on the Iranian government to sign the Additional Protocol by October 31, 2003, after the revelations of clandestine facilities in Natanz and Arak. ${ }^{10}$

6. Many Iranians expressed these and other similar views during the Nuclear Technologies conference in Tehran on March 5-6, 2005. The most elaborate explanations came from Amb. "Ali Asghar Soltanieh, Deputy Director General for International Affairs at the Iranian Ministry of Foreign Affairs in charge of devising Iran's nuclear diplomacy who participated in the conference.

7. Conversations with Iranian officials and scholars, on the sidelines of the conferences in Tehran in March 2005, and in Ankara in January 2006, none of whom wished to be identified.

8. Iran became one of the first signatories of the NPT and the Majlis (Iranian Parliament) ratified the Treaty in February 1970, a month before it entered into force.

9. Compact and comprehensive coverage of the essential points representing Iran's official position can be found in a journal published by the Tehran-based Center for Strategic Studies. See "Peaceful Nuclear Activity and Our Constructive Interaction with the World: An Interview with Dr. Hassan Rohani," National Interest, Vol. 1, No. 1 (Winter 2005), pp. 5-21.

10. With the experience gained from the nuclear inspections in Iraq after the 1991 Gulf War, and the dismantlement of South Africa's nuclear weapons capabilities, the IAEA Board of Governors initiated in

[Continued on next page] 
Had Iran not agreed to sign the Protocol, its dossier in the Board of Governors might have been transferred to the UNSC.

Since the revelation of Iran's undeclared nuclear facilities, the IAEA Director General Mohammed ElBaradei and a group of inspectors have paid frequent visits to Iran and carried out thorough inspections in designated and suspected sites, including parts of the military base in Parchin near Tehran. Since then, a series of reports published by the Agency suggested that "Iranian practices up to November 2003 resulted in many breaches of Iran's obligations to comply with its Safeguards Agreement, but good progress has been made since that time in Iran's correction of those breaches and the Agency's ability to confirm certain aspects of Iran's declarations." 11

The IAEA remained focused on the matter throughout 2005. On August 1, 2005, Iran notified the IAEA that a decision was taken to resume uranium conversion activities at the conversion facility in Esfahan. On August 10, Iran removed the seals on the process lines at the facility. The IAEA immediately urged Iran to re-establish full suspension of all enrichment related activities and to re-instate the seals that had been removed. ${ }^{12}$ With no change in Iran's stance regarding the IAEA's requests, in a subsequent resolution the Agency noted that it was not yet in a position to clarify some important outstanding issues and that Iran's full transparency was indispensable. The IAEA also indicated that it was uncertain about the motives of Iran and that it was concerned by continuing gaps in the Agency's understanding of proliferation sensitive aspects of Iran's nuclear program. ${ }^{13}$ Despite repeated calls from the IAEA Board for Iran to maintain the suspension of all enrichment related and reprocessing activities, Iran's attitude did not change. Hence, the IAEA called on Iran to understand that there was a lack of confidence in its intentions in seeking to develop a fissile material production capability. The Board of Governors subsequently requested the Director General to report on the implementation of the resolutions on Iran and to convey that report to the UNSC after the March 2006 Board meeting. ${ }^{14}$

[Continued from previous page]

1993 a study called "Programme 93+2" with a view to strengthening the NPT's verification mechanism. This study, which was terminated in December 1995, was adopted by the IAEA as INFCIRC/540, also known as Additional Protocol. Unlike the Model Protocol INFCIRC/153 that was drafted in 1971 and which must be adopted by all Non-Nuclear-Weapons States Parties to the NPT in order to conclude a Safeguards Agreement with the IAEA, the Additional Protocol need not be adopted. For a discussion on the Additional Protocol and its implications in the context of Iran's nuclear program see Chen Zak, Iran's Nuclear Policy and the IAEA: An Evaluation of Program 93+2 (Washington DC: The Washington Institute for Near East Policy, 2002). Also see Theodore Hirsch, "The IAEA Additional Protocol: What It Is and Why It Matters," The Nonproliferation Review, Vol. 11, No. 3 (Fall-Winter 2004), pp. 140-166.

11. See "Implementation of the NPT Safeguards Agreement in the Islamic Republic of Iran," Resolution Adopted by the Board 29 November 2004 (GOV/2004/90), p. 1.

12. See "Implementation of the NPT Safeguards Agreement in the Islamic Republic of Iran and Related Board Resolutions," Resolution Adopted by the Board 11 August 2005 (GOV/2005/64), p. 1.

13. See "Implementation of the NPT Safeguards Agreement in the Islamic Republic of Iran," Resolution Adopted by the Board 24 September 2005 (GOV/2005/77), p. 2.

14. See "Implementation of the NPT Safeguards Agreement in the Islamic Republic of Iran," Resolution Adopted by the Board 4 February 2006 (GOV/2006/14), pp. 2-3. 


\section{$212 \star$ MIDDLE EAST JOURNAL}

\section{THE INITIATIVE OF THE EUROPEAN UNION}

The foreign ministers of three leading members of the EU, namely the United Kingdom, France, and Germany, paid a historic visit to Tehran in October 2003 on the eve of the "deadline" set by the IAEA Director General for Iran to sign the Additional Protocol. Since then, the "EU-3" and Iran have met periodically to sort out a workable solution to the confrontation between Iran, who claims to have the right to enrich uranium to use in civilian nuclear reactors, and the US, who asserts that Iran could soon become a de facto nuclear weapons state, and thus must terminate its enrichment-related activities.

The EU-3 and Iran reached a temporary agreement on November 15, 2004: the Iranian government decided, on a voluntary basis, to continue to extend its suspension, which had been in effect for about a year. This suspension included all enrichment related and reprocessing activities, and specifically the manufacture and import of gas centrifuges and their components as well as the work on plutonium separation. ${ }^{15}$ Iran and the EU-3 also emphasized that suspension of enrichment was not a legal obligation and that Iran had rights under the NPT that could be exercised without discrimination. ${ }^{16}$ In this way, the EU remained true to its longstanding policy of using diplomacy to find solutions to international problems rather than resorting to military force. The US, however, saw this initiative as "a waste of time" and said the EU allowed Iran time to build nuclear weapons.

The negotiations between Iran and the EU-3 came to a halt in the spring of 2005 mainly due to two reasons. One was the acknowledgment of the EU's inability to fully satisfy Iran's economic and political expectations in return for its voluntary suspension of enrichment related activities. The other reason was the coming of the presidential elections in Iran. The EU wanted to see first who would come to office and if there would be a change in Iran's policy with respect to the nuclear program. The election of Mahmud Ahmadinejad as President and his bitter statements about Israel, coupled with his stubborn commitment to resuming enrichment activities, made it very difficult for the EU-3 to come back to the negotiation table. After a series of meetings among themselves, and in consultation with the US, the EU-3 cleared the way for the IAEA to take Iran's nuclear dossier to the UNSC.

15. Iran decided in October 2003 to voluntarily and temporarily suspend its enrichment activities in order to facilitate the Agency's technical verification activities in resolving the outstanding issues stemming from the findings of traces of highly enriched uranium in the samples taken from the secretly built pilot scale uranium enrichment facility in Natanz. Iranian authorities claim that the presence of highly enriched uranium (HEU) as well as low enriched uranium (LEU) was due to contamination caused by the centrifuges that were imported from a third party but never operated. Conversations with Amb. 'Ali Asghar Soltanieh on the sidelines of the 55th Pugwash Conference on "60 Years After Hiroshima and Nagasaki" convened in Hiroshima on July 24, 2005, and in a panel on "Iran's Nuclear Program" in Ankara on November 16, 2005.

16. See "Communication dated 26 November 2004 received from the Permanent Representatives of France, Germany, the Islamic Republic of Iran and the United Kingdom concerning the agreement signed in Paris on 15 November 2004," INFCIRC/637, November 26, 2004, p. 3. 


\section{IRAN'S NUCLEAR PROGRAM UNDER THE SHAH}

Iran's acquaintance with nuclear science and technology goes back to the years when the US increased its assistance to Iran in the economic, military, and technical fields in the aftermath of World War II. ${ }^{17}$ These were also the years when the US wanted its share in the burgeoning nuclear market. As part of the intensifying relations, the US and Iran signed the Agreement for Cooperation Concerning Civil Uses of Atoms in 1957 after two years of negotiations. ${ }^{18}$ Eventually, American Machine and Foundry (AMF) supplied Iran with a pool-type $5 \mathrm{MW}$ (th) reactor and its fuel in September $1967 .{ }^{19}$ At the same time, the scientific infrastructure of Iran was also steadily growing with hundreds of Iranian students attending universities in Western Europe and the US; technicians were also mastering skills in traineeship programs abroad. In the 1970s, there was a major inflow of trained scientists and technologists back to Iran. With Iranian universities establishing nuclear research and technologyrelated departments, by the time the Shah announced his ambitious nuclear power program in 1974, there was a relatively good scientific base in the country. ${ }^{20}$

Iran's cooperation with the US in the nuclear field gained impetus with the historic visit of President Richard Nixon to Tehran in May 1972. The visit was the result of a fundamental shift in power relations in the Persian Gulf which began with the "Nixon Doctrine" of 1969. This doctrine outlined the "US intent to place greater emphasis on initiatives by regionally influential states to assure stability and security of their respective regions." ${ }^{21}$ The Nixon Administration wanted to enhance the Shah's strength in order to deter Soviet designs on the region. ${ }^{22}$

Following the 1973 Arab-Israeli War, oil prices quadrupled overnight. ${ }^{23}$ This huge influx of dollars enabled the Shah to expand the scope of the nuclear energy

17. For a detailed analysis of US-Iran relations, see Kenneth M. Pollack, The Persian Puzzle: The Conflict Between Iran and America (New York: Random House, 2004).

18. “Atoms for Peace Agreement with Iran," Department of State Bulletin, No. 36, April 15, 1957; cited in Muhammad Sahimi, "Iran's Nuclear Energy Program. Part V: From the United States Offering Iran Uranium Enrichment Technology to Suggestions for Creating Catastrophic Industrial Failure," Payvand's Iran News, December 22, 2004, p. 2, http://www.payvand.com.

19. See "US Supplied Nuclear Material to Iran, September 1967 to May 1976," Non-Classified, Chart State, Digital National Security Archives, hereafter DNSA (Item Number IR03551), Washington DC, January 29, 1980. p. 1. The archives are available at http://www.nsarchive.chadwyck.com.

20. See Akbar Etemad, "Iran," in Harald Muller, ed., A European Non-Proliferation Policy: Prospects and Problems (Oxford: Clarendon Press, 1987), pp. 203-227.

21. Public Papers of the Presidents: Richard Nixon, 1969, pp. 544-548; cited in "The Evolution of the US-Iranian Relationship: A Survey of US-Iranian Relations, 1941-1979," Top Secret, Report State, DNSA (Item Number IR03556), Washington DC, January 29, 1980, p. 44.

22. The President was advised by his staff to "assure the Shah that the US envisioned Iran carrying a large share of the responsibility for security of the Persian Gulf." "Visit of Richard Nixon to the Empire of Iran, May 1972 - Issues and Talking Points," Secret, Briefing Book State, DNSA (Item Number IR00767), Washington, DC, May 12, 1972, p. 2.

23. US logistical support for Israel, and continued Israeli occupation in the Yom Kippur War, caused much anger and resentment among Arab nations, including the oil-rich monarchies. 


\section{$214 \star$ MIDDLE EAST JOURNAL}

projects. In March 1974, the Shah announced plans for developing 23,000 MW(e) of nuclear power capacity "as soon as possible." ${ }^{4}$ To achieve this goal, the Shah established the Atomic Energy Organization of Iran (AEOI) the same year. In May 1974, the Chairman of the US Atomic Energy Commission traveled to Tehran to talk to Iranian officials about establishing multinational uranium enrichment and reprocessing facilities in Iran. The scope of cooperation would be further expanded with the visit of the Secretary of State Henry Kissinger in November 1974. On March 3, 1975, Iran and the United States signed a $\$ 15$ billion agreement for the construction of eight nuclear reactors having a total capacity of $8,000 \mathrm{MW}(\mathrm{e}) .^{25}$

In addition to US investments in Iran's nuclear program, Iran proposed to invest $\$ 2.75$ billion in a uranium enrichment facility in the US. ${ }^{26}$ The US was equally willing to let Iranians invest in establishing a spent fuel reprocessing facility in Iran, preferably as a multinational facility. Around the same time, the Massachusetts Institute of Technology signed a contract with Iran to provide training for Iranian nuclear engineers.

The Carter Administration pursued much the same policy of cooperation. On April 12, 1977, Iran and the US signed an agreement to exchange nuclear technology and cooperate in nuclear safety. In his visit to Tehran on December 31, 1977 and January 1, 1978, President Carter reached a new agreement according to which the US granted Iran "most favored nation" status for spent fuel reprocessing. Then, on July 10, 1978 in Tehran the US-Iran Nuclear Energy Agreement was signed; this agreement was to facilitate cooperation in the field of nuclear energy and to govern the export and transfer of equipment and material to Iran. ${ }^{27}$

\section{NUCLEAR COOPERATION WITH THE EUROPEANS}

France and Germany have also played a significant role, both in the expansion of Iran's nuclear infrastructure and in raising a cadre of Iranian professionals and

24. Indeed, the first announcement regarding Iran's intention to establish nuclear reactors was made on December 18, 1972, when Iran's Ministry of Water and Power began a feasibility study for constructing a nuclear power plant in southern Iran. See Tehran Magazine (March 18, 1974), p. 2, cited in Sahimi, "Iran's Nuclear Energy Program. Part V," p. 2.

25. The Ford Administration agreed to the proposal and decided to set the fuel ceiling at a level reflecting the approximate number of nuclear reactors Iran planned to purchase from US suppliers under the proviso that the fuel would represent Iran's entitlement from their proposed investment in an enrichment facility in the US. The Agreement was signed by Secretary Henry Kissinger for the US and Finance Minister Houshang Ansari for Iran. See, Sahimi, “Iran’s Nuclear Energy Program, Part V,” p. 4.

26. “US-Iran Nuclear Cooperation," National Security Decision Memorandum 292, National Security Council, Washington, President Gerald R. Ford's Presidential Documents, April 22, 1975, http:// www.ford.utexas.edu/library/document/nsdmnssm/nssm292a.htm, p. 1.

27. The US-Iran Agreement would be the first such bilateral agreement submitted to Congress under the general framework of the Nuclear Non-Proliferation Act of March 10, 1978. But, the Islamic Revolution of February 1979 put all nuclear cooperation between the US and Iran on hold. See, "Iran: The US-Iran Nuclear Energy Agreement," Confidential, Briefing Paper State, DNSA (Item Number IR01605), Washington DC, October 20, 1978, p. 1. 
scientists in the 1970s. In 1974, Iran signed contracts with the French company Framatome to build two $950 \mathrm{MW}(\mathrm{e})$ pressurized water reactors and the site preparation work began in Darkhovin. In 1975, Iran purchased a 10\% share in the uranium enrichment company, Eurodif, which was a joint venture between France, Belgium, Spain, and Italy. ${ }^{28}$ In connection with these contracts, a significant number of Iranian students, scientists, and technicians have gone to France to advance their skills and knowledge in nuclear engineering, nuclear physics, and related branches.

On the other hand, Germany and Iran reached an agreement in 1976 for the establishment of six nuclear power reactors in Iran; the first two were to be built by German Kraftwerk Union (KWU) in Bushehr, each housing Siemens 1,300 MW(e) reactors. Iran also concluded nuclear fuel contracts with Germany in 1976. ${ }^{29}$ There were also negotiations between Germany and Iran for selling uranium enrichment technology to Iran. ${ }^{30}$ Additionally, there was a huge program to train Iranian nuclear scientists in Germany. ${ }^{31}$

\section{IRAN'S NUCLEAR PROGRAM AFTER THE ISLAMIC REVOLUTION}

The Revolution caused a dramatic change in Iran's disposition in the world political arena vis-à-vis foreign and security policy matters; after the "hostage crisis" in the US Embassy in Tehran, Iran would no more be seen as an ally of the US. ${ }^{32}$ On the contrary, "hostility" would best characterize the nature of Iran-US bilateral relations after 1979. The US not only stopped cooperating with Iran in the nuclear field, but also pursued a "policy of denial" by putting pressure on other countries not to transfer nuclear technology to Iran.

\section{First Years OF The ReVolution: "Neither East, Nor West"}

The fundamental guiding principle of revolutionary Iran's foreign policy was Imam Khomeini's slogan "Na Sharq, Na Gharb, Faqat Jumhuri-ye Islami:" "Neither

28. Iran's contract with Eurodif specified the supply of about 270 tons of uranium enriched to $3 \%$ in U-235. See Frank Barnaby, How Nuclear Weapons Spread: Nuclear-Weapon Proliferation in the 1990s (London: Routledge, 1993), pp. 114-117.

29. See Haleh Vaziri, "Iran's Nuclear Quest: Motivations and Consequences," in Raju G. C. Thomas, ed., The Nuclear Non-Proliferation Regime (Princeton, N. J.: Princeton University Press, 1986), p. 311.

30. Barnaby, How Nuclear Weapons Spread, p. 114.

31. According to Prof. Erwin Haeckel, Senior Researcher in the German Council on Foreign Relations, as of the late 1970s, there were hundreds of Iranian students in German universities studying nuclear physics and nuclear engineering. Interview with Prof. Erwin Haeckel on the sidelines of the Conference on "Germany and Nuclear Nonproliferation" held in Berlin, February 25-27, 2005.

32. On November 4, 1979, Iranian militants and students stormed the US Embassy in Tehran and held hostage some 70 diplomats and citizens of the United States. On April 24, 1980, the United States attempted a rescue mission that failed. On January 20, 1981, the day of President Reagan's inauguration, the hostages were released. 
East, nor West, only the Islamic Republic [of Iran]." ${ }^{33}$ In the early years of the Revolution, almost anything Western was rejected, and the nuclear projects were no exception. Ayatollah Khomeini's return from exile to Tehran on February 1, 1979 ushered in a brief but intense anti-modernization phase in Iran's domestic and foreign policies.

The clerics rejected the Shah's plans to finance the rapid modernization of the civilian and military infrastructures with Iran's oil revenues. In fact, they reduced oil exports, allowed much of the American military hardware purchased by the Shah to fall into disrepair, purged the armed forces of suspected opponents, and did not impede the flight of many scientists who had worked on Iran's nuclear projects. ${ }^{34}$

As regards the AEOI, there was a tendency to destroy everything within it, and many people - professional and otherwise — had a say in the matter. The destructive forces of the Revolution inside and outside the AEOI succeeded in bringing nearly all the projects to a halt; all the major projects were cancelled or left dormant. ${ }^{35}$

\section{Attempts To Resume IRan's Nuclear Program: Both East And West}

The Iraqi offensive against Iran, especially the massive air strikes on ports and oil refineries in the Persian Gulf, showed the clerics that modern military technology, especially weapons of mass destruction, could make a decisive difference in war. The first four or five years of the Iran-Iraq War shocked the clerics into realizing the value of modern military technology. The use of such technology - and perhaps even nuclear weapons capability - would have deterred Iraq's initial aggression against the Islamic Republic and flouted the international laws of war conduct. From the clerics' perspective, the Reagan Administration not only had opposed their hegemonic aspirations but also allied with Iraqi Ba'th in an effort to defeat Iran. Had the Islamic Republic possessed nuclear weapons, the US may have thought twice about interjecting its Navy into the Persian Gulf and engaging Iranians. ${ }^{36}$

The severe energy crisis in the post-revolutionary period was also a reason for the top Iranian clergy to change their attitude toward nuclear projects. The construction of power plants was given high priority. The clerics "realized that they had killed the goose which laid the golden egg" by destroying the AEOI ${ }^{37}$ They decided to revive the organization with a new president who would resolve the issues with the German Kraftwerk Union in order to resume building the Bushehr nuclear power plant. The German firm refused, probably in response to pressure from the US. Nor

33. Persian version of the slogan is borrowed from Haleh Vaziri. See her chapter on "Iran's Nuclear Quest," p. 314.

34. Vaziri, "Iran's Nuclear Quest,” p. 315.

35. Etemad, "Iran," p. 214.

36. Vaziri, "Iran's Nuclear Quest," p. 316.

37. Dr. Akbar Etemad notes, "some government officials even explicitly blamed those who had decided to cancel the Bushehr nuclear power plant project. It was said that one of the causes of the shortages of power was the failure of government to implement the project," which was expected to become operational in the early 1980s. See Etemad, "Iran,” p. 214. 
did the French company Framatome agree on two 950 MW(e) reactors at Darkhovin, or on the construction of the Esfahan Nuclear Research Center. President Hashemi Rafsanjani recalled that at that point they realized that the West was not going to give sensitive technology to Iran. ${ }^{38}$

Thus, Iran turned to other potential suppliers such as Pakistan, Argentina, Spain, Czechoslovakia, China, and the Soviet Union. In 1987, Iran signed a nuclear cooperation agreement with Pakistan; according to the agreement, 39 Iranian nuclear scientists and technicians would advance their skills in Pakistani nuclear facilities, reactors, and laboratories. ${ }^{39}$ In May of the same year, Iran signed a $\$ 5.5$ million agreement with Argentina for the supply of uranium enriched to $20 \%$ and for the training of Iranian scientists at the Jose Balaserio Nuclear Institute. ${ }^{40}$ But Iran's relentless efforts to resume work at the nuclear sites did not come to fruition. ${ }^{41}$ Thus, China and Russia appeared as viable alternatives for nuclear assistance.

In the midst of the war with Iraq, the Esfahan Nuclear Research Center was opened in 1984; this demonstrated the Islamic regime's determination to pursue the nuclear aspirations inherited from the Shah's regime. With Chinese assistance, fuel fabrication and conversion facilities, which are crucial for uranium enrichment, were built at Esfahan. In 1991, China and Iran announced an agreement to supply Iran with a 20 MW research reactor from China. ${ }^{42}$ In September 1992, President Rafsanjani negotiated with Chinese President Jiang Zemin for the purchase of one or two 330 MW(e) reactors; a tentative agreement to buy one such reactor was announced by the Iranian Defense Minister during the visit to Beijing. This announcement led to immediate US protests to China resulting in the deferral of the sale.

Iran also had held earlier talks with Russia in the late 1980s and had even agreed in principle to cooperate in the nuclear field. In an address to the Nuclear Technologies Conference in Tehran in March 2005, President Rafsanjani said he remembered taking the initiative and talking with President Gorbachev about the completion of the Bushehr power plant. But their agreement was delayed by the collapse of the communist regime in the Soviet Union. President Rafsanjani recalled that "Russia would support Iran to finish Bushehr in six years and they said they would start from scratch,

38. Rafsanjani made this statement during his address to the closing session of the "International Conference on Nuclear Technologies and Sustainable Development" convened in Tehran on March 6, 2005. Author was present for the statement.

39. Vaziri, "Iran's Nuclear Quest," p. 318.

40. Etemad, "Iran," p. 216.

41. In the meantime, the Iraqi Air Force attacked the Bushehr site several times causing serious structural damage. The Iraqi bombings occurred on March 24, 1984; February 12, 1985; March 4, 1985; July 12, 1986; November 17, 1987; November 19, 1987; and July 19, 1988. See Anthony H. Cordesman, Iran and Nuclear Weapons (Washington, DC: Center for Strategic and International Studies, 2000), p. 7.

42. Both countries have stressed that the reactor was intended solely for peaceful purposes, and Iran agreed to allow IAEA safeguards. See the website of the Nuclear Threat Initiative (NTI) of the Center for Nonproliferation Studies at the Monterey Institute of International Studies in Monterey, CA, US, available online at http://www.nti.org/db/china/ncaorg.htm. 
and we said OK." ${ }^{43}$ A Nuclear Cooperation Accord was signed between Russia and Iran on January 8, 1995 in Tehran. Russia agreed to complete the construction of Block No. 1 at the Bushehr nuclear power plant and to train AEOI's scientific personnel as well as 10-20 graduate students and Ph.D.s annually at Russian academic institutions. ${ }^{44}$ The Russia-Iran nuclear deal would cost nearly $\$ 1$ billion, and the first of the two Russian-designed VVER-1000 reactors was originally planned to become operational by 2001.

Dr. Asadullah Sabouri of AEOI says, in this respect, "the first reactor at the Bushehr nuclear power plant will start operation in December 2006 with 300 Iranian engineers and 400 technicians running the reactor. Due to close cooperation with Russia and the IAEA, Iran's regulatory infrastructure is enhanced, in the areas of reviewing safety reports, seismic hazard evaluation, reviewing design documents, establishment of quality management systems, and the physical protection of the plant. ${ }^{45}$ Regarding the level of education in the nuclear field, Dr. Mahmood Reza Aghamiri from Shahid Beheshti University says, "at present, there are 45 departments in Iranian universities in the nuclear area and there are plans for 80 departments in the medium to long term. There are eight nuclear research centers, which will grow to 15 in the future. And there are 450 post-graduate students (mostly engineers) in the nuclear field; this will grow to 1,500 in the future."46

\section{IRAN'S MOTIVATIONS AND INTENTIONS}

Iran's efforts to build an elaborate nuclear infrastructure raise simple but highly crucial questions: Does Iran intend to build nuclear weapons? If so, why and when? Answering these questions is not easy. One approach is to talk with Iranian experts, scholars, and officials, to learn what they expect from their ambitious nuclear program, what they perceive as a threat, what they think about nuclear weapons, and what they think about going nuclear. ${ }^{47}$

43. Rafsanjani's address to the Nuclear Technologies conference in Tehran, Iran on March 6, 2005.

44. English translation of the full text of the Nuclear Cooperation Accord can be found in Michael Eisenstadt, Iranian Military Power: Capabilities and Intentions, (Washington, DC: The Washington Institute for Near East Policy, 1996), pp. 106-107.

45. Author's notes from the presentation of Dr. Sabouri in a panel on "Iran's Peaceful Nuclear Program: Requirements and Imperatives," during the International Conference on Nuclear Technologies and Sustainable Development in Tehran on March 5, 2005.

46. Author's notes from the presentation of Dr. Aghamiri in a panel on "Iran's Peaceful Nuclear Program: Requirements and Imperatives," during the International Conference on Nuclear Technologies and Sustainable Development in Tehran on March 5, 2005.

47. The term "going nuclear" is used to denote the behavior of a number of countries that have decided to develop nuclear weapons, after the book by Leonard S. Spector. See, Leonard S. Spector, Going Nuclear (Cambridge, MA: Ballinger Publishing Co., 1988). 


\section{IRAN's EXPECTATIONS OF ITS NUCLEAR PROGRAM}

Dr. Saeed Khatipzadeh, the editor of the Iranian Journal of International Affairs says, "we want to be admitted to the nuclear club, we want the prestige, and we want to be respected in the world." ${ }^{48}$ Central to the views of Dr. Khatipzadeh is how much the nuclear program is associated with Iranian national pride and prestige. Similar views are expressed by a number of scholars and intellectuals, and by civil and military officials. Dr. Gholamali Chegnizadeh, Assistant Professor in the Faculty of Law and Political Science at the University of Allame Tabatabaee in Tehran, argues,

three pillars of Iranian strategic thinking are important to understand. The first is Iranians' sense of victimization [because of the attitude of the West after the Islamic Revolution, especially during the war with Iraq]. Second is Iranians' quest for recognition. Third is continuity with the pre-Revolutionary period. Iran is a proud country, a big country, and a leading country. This must be recognized. The sense of Iran as a leading country is something to which the leadership pays heavy attention. The psychological deficit within the Iranian leadership could be fulfilled by developing nuclear weapons capability. ${ }^{49}$

\section{IRAN's PERCEPTION OF THREAT}

Iranian authorities refer primarily to the changing security environment in their threat assessments. For instance, Dr. Nasser Saghafi-Ameri from the Tehran-based Center for Strategic Studies, argues that,

despite the end of the Cold War, nuclear weapons continue to be legitimized by treaties like NPT. The American, European, and Russian doctrines stress the value of nuclear weapons in national and collective defense strategies. Today's international system is characterized by American preeminence and unilateralism; and by the increased role of nuclear weapon as a means of political blackmail. These policies foment the nuclear arms race, lower the threshold for resorting to nuclear weapons and dramatically increase the insecurity and vulnerability of non-nuclear weapons states.

Dr. Saghafi-Ameri also argues,

America still keeps 480 nuclear weapons in Europe in six countries, including neighboring Turkey. The Russians had a policy of "no-first-use" but they rescinded it, because they feel that they have become weaker in conventional

48. Conversation with Dr. Saeed Khatibzadeh in Tehran, December 27, 2004. The Iranian Journal of International Affairs is published by the Iranian Institute of Political and International Studies (IPIS), a think tank under the auspices of the Iranian Foreign Ministry.

49. Author's notes from Dr. Chegnizadeh's presentation at the International Conference on Nuclear Technologies and Sustainable Development convened in Tehran on March 5-6, 2005. 
terms. France also decided to follow the US by widening a nuclear strategy that was originally designed to deter the Soviets. The British government maintains and develops the Trident nuclear weapons system. The Chinese are modernizing their nuclear arsenal by increasing the size, accuracy, range, and survivability of their weapons..$^{50}$

\section{VIEWS OF The IRANIAN ELITE ON NUCLEAR WeAPONS}

An elaborate analysis of the views prevailing within the Iranian elite comes from Dr. Nasser Hadian, Associate Professor in the Faculty of Law and Political Science at the University of Tehran. In his analysis, Dr. Hadian identifies four different viewpoints among the Iranian elite regarding the nuclear (weapons) program. According to Dr. Hadian,

the first group consists of those who believe Iran does not need at all nuclear weapons or the capability. These are the so-called "greens" and they constitute only 2 or $3 \%$ of the population. The second group maintains that Iran is entitled to have peaceful nuclear technology and it should not give up its right to peaceful applications of nuclear energy. The third groupb e li e ves Iran needs to develop nuclear weapons capability, but not the weapons at this time. They say Iran cannot trust the international community. They refer to chemical weapons area and point out that they thought the threshold would not be crossed; but when Iraq used chemical weapons against Iran, the West just watched, and did nothing to stop them. The fourth group are the hardliners who strongly argue and push for withdrawing from the NPT and developing nuclear weapons as soon as possible..$^{51}$

Dr. Hadian continues, "the first and the last options are unlikely under normal circumstances; a consensus will be reached somewhere between the second and the third options, which means having the full nuclear fuel cycle and the capability to manufacture nuclear weapons." Dr. Hadian maintains that the second and third groups do not think nuclear weapons would enhance Iran's security; rather nuclear weapons will make Iran a target and will spur further proliferation in the region.

50. Excerpts from Dr. Saghafi-Ameri's presentation, titled "NPT and New International Security Environment," during the Conference on Nuclear Technologies and Sustainable Development convened in Tehran on March 5-6, 2005. Dr. Saghafi-Ameri had expressed similar views to the author during a visit to the Center for Strategic Studies in Tehran on December 26, 2004, in Hiroshima on July 24, 2005 during the 55th Pugwash Conference, and in Como, Italy on November 5, 2005 during a workshop of the Landau Network.

51. Conversations with Dr. Hadian in between two conferences in Tehran, the first on Persian Gulf Security, March 1-2, 2005 and the second on Nuclear Technologies and Sustainable Development, on March 5-6, 2005. 


\title{
Views From Iranian SCIENTific And Bureaucratic CirCles
}

\author{
Dr. Kayhan Barzegar states,
}

there are a significant number of brilliant young scientists who earned their degrees and training in Iranian nuclear research institutions and abroad. The majority hold that, as a regional power with great ambitions, Iran must have nuclear capabilities. After having developed the capability, stopping would be a backward step; our population is $90 \%$ in favor of nuclear power and would not accept that. We spent billions of dollars on the nuclear projects. ${ }^{52}$

Dr. Barzegar adds, "bureaucrats, scientists, and technicians who are directly involved in the nuclear projects are very concerned about halting the uranium enrichment process and stopping the nuclear projects, because they are afraid of losing their jobs and prestige."

\section{Public Support For The Nuclear Program}

Iranian authorities point to wide popular support to validate their pursuit of a complete nuclear fuel cycle. Dr. Seyed Hossein Mousavian, then Head of the Foreign Policy Committee of the Supreme National Security Council, noted in March 2005, "we are under pressure from both the US and the Iranian public in exactly opposite directions." He also argued, "if, under US pressure, we agreed to cease uranium enrichment, which is highly unlikely, then we will most likely be replaced by the hardliners." 53 It is easy to feel the degree of public support in Iran for the nuclear program, which is very much associated with national pride. Iranian people consider nuclear technology to be the most advanced technology, and they see Iran's nuclear capabilities as an indication of their place in the world. It is also seen as a means of equating themselves with the most powerful countries in the international arena.

However, the "public pressure" on Iranian authorities, which they seemed to use very wisely as leverage in their negotiations with the Europeans, is indeed something new, and is, to some extent, "fabricated" by them. This does not mean that it does not exist. On the contrary, it does exist. It is quite explicit everywhere in Iran and is hard to miss. Nevertheless, the public pressure is to some degree a product of the policies and rhetoric of the Iranian leadership over the last few years. According to Dr. Hadi Semati, Assistant Professor at the University of Tehran,

the support did not exist before as knowledge about the program is fairly recent. As more information became available, and public debate about it took a more serious tone, the support seems to have gotten stronger. Five years ago

52. Conversations with Dr. Barzegar on the sidelines of two conferences convened in Tehran in the first week of March 2005.

53. Conversation with Dr. Mousavian in between the two conferences in Tehran on March 4, 2005. 
no or very little discussion existed, as there was no wide public knowledge about the issue. The government now feels somewhat constrained because of this public discourse and the more present nationalism. ${ }^{54}$

\section{Support From The IsLamic World And The Non-Aligned Countries}

Scholars and intellectuals from Islamic nations, Non-Aligned Movement (NAM) countries, as well as Europe and other parts of the world concur with most of the arguments put forward by Iranian authorities. ${ }^{55}$ Some of these thinkers express their individual support for Iran's undertakings in the nuclear field, such as enrichment. Some even suggest that Iranian authorities go further down the road - that they develop nuclear weapons on behalf of all true Muslims in the world, and never give in to the pressure of the US. ${ }^{56}$ However, if and when Iran attains the status of a de facto nuclear weapons state, it may very well constitute a threat to the existing states in the Middle East. It seems that "religion" (Islam, in this case) transcends "national interest" for the peoples of the region who welcome Iran's nuclear aspirations. The Islamic and NAM countries also support Iran's nuclear program in the expectation that they will receive nuclear technology from Iran in the near future. Iran is becoming a "nuclear supplier state" by indigenously developing technologies that originally came from abroad. Therefore, they do not wish to see Iran as setting a precedent of giving up enjoying Article IV rights stemming from the NPT. Amb. Muhammad Shaker from Egypt puts it very clearly: "Iran should not set a bad precedent for other developing countries by foregoing the option of developing indigenous nuclear technologies under the pressure from the US." ${ }^{57}$

54. Author's e-mail communication with Dr. Semati as a follow up to his seminar given at the Massachusetts Institute of Technology on Iran's domestic politics and the nuclear program, on May 4, 2005 in Cambridge, Massachusetts, US.

55. Some of those who expressed views along these lines (their personal views, or the views prevailing among the public in their countries, but not necessarily theirs), either by delivering papers at the Persian Gulf Security conference in Tehran on March 1-2, 2005 or by intervening during the Q\&A sessions were: Dr. Mohammed Saeed Idris from the Al Ahram Center for Political Studies, Cairo; Dr. Abdullah Nafisi from Kuwait; Dr. Rafiullah Azmi from the Zakir Husain Institute of Islamic Studies, New Delhi; Dr. Timo Hellenberg from the University of Helsinki; Dr. Luis Mesa Delmonte from El Colegio De Mexico, Mexico City; Dr. Abduljalil Al-Soufi from Dhamar University, Yemen; Dr. Khalil Makhif Al-Rabee from Baghdad University, Iraq; Dr. Albert Stahel from the University of Zurich; Denis Engelleder from Friedrich-Schiller University, Jena, Germany; Kashif Mumtaz from Institute of Strategic Studies, Islamabad; Anthon Khlopkov from PIR Center, Moscow.

56. These views were expressed during the two conferences convened in Tehran in the first week of March 2005 (see earlier footnotes). However, the participants were most outspoken during an informal lunch in the outskirts of Tehran on the weekend, March 4, 2005. Dr. Mustafa Zahrani, Director of the Iranian Institute of Political and International Studies (IPIS), who organized the "excursion," encouraged the foreign participants "to ask whatever they wanted to know about Iran's nuclear program" saying that "Iranian officials [who were present at the lunch] would answer their questions." The author asked publicly for permission (which was granted verbally by all participants) to use the minutes of the conversations around the table in his scholarly works.

57. Amb. Mohammad Shaker (ret.) made this remark during the working group sessions at the 55th Pugwash Conference in Hiroshima, Japan, July 25, 2005. 


\section{How Long Will It Take IRAN To Build NuClear Weapons?}

There are many factors motivating states to build nuclear weapons: national pride and prestige; the myth of becoming a mighty nation once nuclear capabilities are acquired; the perception of threats to national security from changes in the international political environment; the push for weapons development from the elites and from scientific and bureaucratic circles; the deterioration of the domestic economic and political situation that can be offset by uniting different factions around the nuclear objective; public support coupled with support from other nations that strengthens the hand of politicians. ${ }^{58}$ All these can be found in Iran's bid for nuclear power as discussed earlier in the paper. There is, therefore, good reason to believe that Iranian authorities are seriously considering weaponizing their nuclear capabilities. Prof. Steven Miller from Harvard University argues that it is indeed surprising that Iran has not developed nuclear weapons already. ${ }^{59}$

The question of how long it will take Iran to build nuclear weapons is crucially important. But probably few Iranian authorities can themselves give an exact answer. Building nuclear weapons does not depend only on the political decisions of the leadership. Building weapons depends also on technical capabilities and military expertise. Regarding Iran's technical ability to develop nuclear weapons Dr. Saghafi-Ameri asserts, "there is no doubt Iran has the scientific, technological and industrial base to produce weapons-grade uranium. But this is also true of many other signatories of the NPT who do not belong to the so-called nuclear weapons club."60 Similarly, Dr. Kaveh Afrasiabi from Tehran University argues that in the $21^{\text {st }}$ century building nuclear warheads is not a big deal, implying that Iran has overcome many of the technological difficulties. ${ }^{61}$

There has apparently been collaboration between Iranian scientists and Dr. Abdel Qader (AQ) Khan, a Pakistani nuclear scientist and the mastermind behind an illicit nuclear network. The collaboration may well have included an exchange of sophisticated nuclear weapons designs. If this is so, it would shorten considerably the time needed for Iran to build a bomb. Regarding this collaboration, an Iranian expert who

58. For an analysis of theoretical approaches to nuclear proliferation see Tanya Ogilvie-White, "Is There a Theory of Nuclear Proliferation? An Analysis of the Contemporary Debate," The Nonproliferation Review, Vol. 4, No. 1 (Fall 1996), pp. 43-60. Also see Stephen M. Meyer, The Dynamics of Nuclear Proliferation (Chicago: The University of Chicago Press, 1984); Scott D. Sagan, "Why Do States Build Nuclear Weapons? Three Models in Search of a Bomb," International Security, Vol. 21, No. 3 (Winter 1996/97), pp. 54-86; Benjamin Frankel, "The Brooding Shadow: Systemic Incentives and Nuclear Weapons Proliferation,” Security Studies, Vol. 2, Nos. 3-4 (Spring-Summer 1993), pp. 37-40; Peter R. Lavoy, "Nuclear Myths and the Causes of Nuclear Proliferation," Security Studies, Vol. 2, Nos. 3-4 (Spring-Summer 1993), pp. 199-202.

59. Interview with Prof. Steven Miller at the Belfer Center for Science and International Affairs at Harvard University, June 28, 2005, Cambridge, MA, US.

60. Excerpts from Dr. Saghafi-Ameri's paper, titled "NPT and New International Security Environment."

61. Conversation with Dr. Kaveh Afrasiabi, December 26, 2004, Tehran, Iran. 
is involved in nuclear issues in Iran says, "AQ Khan has given Iranian scientists simple but crucial information because, he believes that Islamic nations should collaborate in this area to counter the others who have nuclear-weapons capabilities." ${ }^{2}$

Dr. Saeed Khatibzadeh has said, "some Iranian experts believe that we have the capability to build a nuclear device. Some of them say we need one year, others say three years." ${ }^{63}$ However, Dr. Khatipzadeh also emphasizes that "having the capability to make the bomb doesn't mean that we will make the bomb and use it right away. We know the limits of developing and using nuclear weapons. If we are forced to develop nuclear weapons, we will then be a different country and we will have different difficulties."

\section{IMPLICATIONS OF IRAN'S NUCLEARIZATION}

If Iran becomes a suspected or a de facto nuclear weapons state, it is feared that its neighbors such as Iraq, Saudi Arabia, Egypt, Syria, and Turkey, may consider their nuclear options. Dr. Richard Russell, from the National Defense University says, "from Iraq's perspective, even with Saddam Husayn gone, a nuclear Iran will pose an acute security dilemma." ${ }^{\prime 4}$ Iran may use its nuclear card as a means of political coercion or as an actual battlefield tactic, placing extraordinary pressure on Iraq to consider nuclear alternatives.

The possibility of a nuclear Saudi Arabia should not be ruled out, given its partnership with the United States. Not only is its traditional Gulf rival, Iran, obtaining nuclear weapons, but Saudi Arabia is also concerned about what the Iraqi future will look like. There is the ongoing security concern of Israel, and even the possibility of future hostilities with the United States. All these make the nuclear option a tempting quick fix for present and future security dilemmas. ${ }^{65}$

Egypt, despite its close security relationship with the United States, may well consider nuclear alternatives on the basis that it no longer carries the prestige in Arab politics that it once did. Its power is not at all commensurate with its population base, and a nuclear Iran would be yet another insult to Egyptian prestige. In addition, notwithstanding assistance from the United States, Egypt must also worry about its conventional military capability. Obtaining nuclear weapons would not only resurrect its lost political status, it would also provide leverage in future negotiations ${ }^{66}$ Egyptian authorities, civil and military, have told the author, time and again, that if another

62. Conversations with an Iranian expert in Tehran in December 2004 who initially agreed but later declined to be cited, arguing that there are sensitivities in Iran regarding the nuclear issues.

63. Conversation with Dr. Saeed Khatibzadeh, December 27, 2004, Tehran, Iran.

64. Notes from the speech of Dr. Richard Russell at the Washington Institute for Near East Studies in a panel "Beyond Iran: The Risk of Nuclearizing Middle East," on February 9, 2005, Washington, DC, US.

65. See in this respect Richard Russell "A Saudi Nuclear Option," Survival, Vol. 43, No. 2 (Summer 2001), pp. 69-79.

66. Russell, "Beyond Iran,” at the Washington Institute, February 9, 2005. 
country in the Middle East acquires nuclear weapons capability Egypt will immediately follow suit. ${ }^{67}$

The strategic calculus of Syria may also point towards nuclear attainment. With an ambiguous future in Iraq and with Israel to the south, Syria occupies a position that is extraordinarily isolated, insecure, and vulnerable. Such a position may provide powerful incentives to develop nuclear weapons.

Turkey and Iran have not had a serious dispute since the 1630s, but this should not suggest that they have always had friendly relations. The parity that exists between them in geographical location, demographic structure, and military capability has made both sides exercise restraint, even though they may have had ambitions to attack each other. Should Iran develop nuclear weapons capability, the balance may tip dramatically in favor of Iran. Developing nuclear weapons has not been a state policy in Turkey. However, if the US and the EU fail to convince Iran to forego the nuclear weapons option, Turks (especially from the younger generations) may not remain loyal to the norms of the nonproliferation regime. ${ }^{68}$

\section{CAN A NuClear IRAN BRING Stability To The MidDle EAST?}

Notwithstanding these possible consequences of Iran's nuclearization, a group of scholars and intellectuals have put forward the idea that Iran's acquisition of nuclear weapons would indeed bring stability to the Middle East. The proponents of this view argue that a nuclear weapons capable Iran will feel more secure and self-confident and will therefore soften its hardline rhetoric toward Israel. Kenneth Waltz argues that the presence of nuclear weapons in the military arsenals of the rival countries will force them to behave more rationally and more carefully by taking into consideration the possible effects of a nuclear exchange. ${ }^{69}$ Those who support such arguments base their reasoning on the success of "Mutually Assured Destruction." Throughout the Cold War period both the US and the Soviet Union had "second-strike capability" and could strike back powerfully even if subjected to a large-scale nuclear offensive.

The proponents of the above-mentioned view must consider a number of factors. First and foremost, Iran's acquisition of nuclear weapons will be a huge blow to the nuclear nonproliferation regime, which has undergone difficult times since North Korea withdrew from the NPT and declared in February and April 2005 that it possesses nuclear weapons. The weakening of the regime may have other consequences such as prompting many countries to seek nuclear weapons manufacturing capabili-

67. Author's interviews with Egyptian scholars, diplomats, and military officials in various scholarly gatherings since the late 1990s.

68. Excerpts from the speech of Dr. Mustafa Kibaroglu at the Washington Institute for Near East Studies in a panel "Beyond Iran: The Risk of Nuclearizing Middle East," on February 9, 2005, Washington, DC, US. Also see Mustafa Kibaroglu, "Iran's Nuclear Program May Trigger the Young Turks to Think Nuclear," Carnegie Analysis, available at: http://www.carnegieendowment.org/npp/publications/ index.cfm?fa=view\&id=16284.

69. See, Scott D. Sagan and Kenneth N. Waltz, The Spread of Nuclear Weapons: A Debate (New York: W. W. Norton \& Co, 1995). 
ties. The impact of Iran's nuclearization may be felt most in the Middle East as discussed earlier. The end result may be the over-arming of a highly volatile region, which is already equipped with all sorts of weapons systems, both conventional and unconventional. A spark may be enough to "explode" the entire region in almost every meaning of the word.

The comparatively compact geographical size of the region is significant when compared to the distances involved in the US-Soviet context; there is therefore no lead time to prevent a crisis from escalating to hot confrontation. Parties may wish to resort to their nuclear weapons under pressure of the "use it or lose it" principle.

The far-reaching consequences of nuclear warfare do not need explanation. Preventing a nuclear exchange requires elaborate command and communication systems both within states and between the states that may become opponents. One cannot be optimistic about achieving a viable degree of communication between Iran and Israel. Even then, maintaining stability in relations would require the parties to have "secure second-strike capabilities" that would deter them from initiating the first strike with the anticipation of annihilating the enemy.

Even if states somehow achieve capabilities that force them to exercise restraint in their political decisions, there will always be the risk of unintentional or inadvertent warfare; there can always be misperception, miscalculation, or technical failures in weapons systems or command and communication systems. Maintaining these capabilities is extremely costly and requires a highly sophisticated security culture coupled with technical and technological capabilities. Given the realities of the Middle East and given the potential nuclear proliferation triggered by Iran's weaponization, the probability of catastrophe is very high indeed.

\section{SCENARIOS TO DEAL WITH IRAN'S NUCLEAR AMBITIONS}

The US has been the most outspoken critic of Iran's nuclear program, especially after the revelations of secret facilities in Natanz and Arak. The US has consistently underscored the need for taking outright action against Iran to stop advancing its nuclear capabilities. In the absence of concerted action by the international community, the US may wish to act alone or possibly with a few close allies such as Israel. There are conflicting recommendations as to what the US should do. While some argue that the US must be tough on Iran and should pursue a "stick only" policy to reverse the course of Iranian ambitions, others suggest engaging Iran and persuading the leadership that developing nuclear weapons is not in their best national interest.

Given Iran's insistence to enrich uranium, which it had suspended voluntarily for a limited period until January 2006, the US faces essentially three options to stop Iran from going further down the road to become a de facto nuclear weapons state. The first possibility is to stage "regime change" and bring in an administration that might renounce nuclear weapons. The second is to carry out a "military strike" (limited in scope and purpose) against carefully selected nuclear installations to set the nuclear program back several years. The third is to "engage" Iran diplomatically and apply a "carrot and stick" policy to convince the mullahs that it is not in their best 
interest to pursue a complete nuclear fuel cycle. Each of these options involves difficulties when considered in light of Iran's realities.

\section{STAGING “REGIME CHANGE” IN IRAN}

Among the younger generation there is little knowledge of the Shah and the factors that led to his overthrow and the Islamic Revolution. This generation is particularly dissatisfied with the current administration. In the summer of 1999, in an attempt to protest the clerical regime, many Iranian students demonstrated in the streets of Tehran, but they were violently suppressed..$^{70}$ There is "a widespread belief among Iranians that it is highly unlikely to see similar scenes in the streets of Tehran any time soon." ${ }^{\prime 11}$ Moreover, when it comes to the nuclear weapons issue, those in the opposition are similar to the regime supporters. They "also want the bomb, but not in the hands of the mullahs." 72 Therefore, the theory of "regime change" even with a slim chance of success in the foreseeable future, apparently will not work in Iran as far as denouncing nuclear weapons capability is concerned.

\section{Limited Military Strike Against Nuclear Facilities}

A "limited military strike" against selected facilities is indeed said to be "doable" by US authorities. However, the outcome of such an act is unclear and there are a number of questionable issues. For instance, with the level of available intelligence, US authorities cannot be sure of hitting all the facilities that have a role in Iran's nuclear program. Therefore, even if the attack were militarily successful, it might not have the desired political result; Iran might soon resume its nuclear program with the indigenous capabilities acquired over many years, but this time it might be even more determined to develop nuclear weapons.

Another issue is the high probability of retaliation by Iran in order to "cause damage to US interests from Afghanistan to Iraq and Lebanon."73 Iran could retaliate militarily against the US troops stationed in Iraq or Afghanistan and could mobilize "everything in its capability" (including non-state actors such as Hamas and Hizbullah in Palestine and Lebanon) to challenge the Palestine-Israel peace process. Or it could try to impede the state-building efforts in Iraq by using its influence on the Shi'a majority. Some groups may act without orders from Tehran to commit terror against the US and its citizens all around the world. ${ }^{74}$ American citizens would then quite

70. See, for instance, Brief on Iran, No. 1191, July 21, 1999, published by the Representative Office of The National Council of Resistance of Iran, which is an opposition group based in Washington, DC, available at: http://www.iran-e-azad.org/english/boi/11910721_99.html.

71. Conversations with graduate students in Iran who identified themselves as being in the opposition. Their names will not be cited here.

72. Conversations with the students in the opposition.

73. Conversations with Dr. Saeed Khatibzadeh.

74. Conversations with Dr. Kaveh Afrasiabi. 
rightfully ask whether Iran's nuclear program was posing a big enough threat to the US to justify what Americans would have to endure after the strike. As some American analysts argue, "Iran's nuclear (weapons) program does not pose an existential threat to the US." 75

\section{ENGAGING IRAN With "CARRot AND STICK”}

The third option is to use "carrot and stick" diplomacy in order to engage Iran. This would mainly entail economic incentives to Iran "to restore its crippling economy" in return for giving up uranium enrichment. If Iran does not agree to cooperate, the stick of sanctions would apply. ${ }^{76}$ This option also has a number of difficulties. First and foremost, there must be a common definition of the act of "engagement." It seems that Americans and Iranians attribute different meanings to the same word. For Iranians, engagement means economic benefits while nuclear activities — including uranium enrichment - continue under stringent inspections. For Americans, engagement means eventual normalization of economic and even political relations provided Iran quits enrichment indefinitely, changes its attitude toward Israel, and gives up its support of Hizbullah.

A second difficulty with engagement is the obvious misinterpretation of Iran's economic situation by American analysts. What may be an "unbearable economic situation" for an American security analyst in Washington, DC may have no realworld meaning for an Iranian who has lived in a rather closed economy for 25 years under the sanctions imposed by the US. ${ }^{77}$ Therefore, what American analysts may see as an "attractive incentive" may be too small to persuade Iranian decision makers to give up the nuclear program that is so associated with national pride. ${ }^{78}$ It is obvious that there is no easy way out of this highly complex situation where the positions of the parties are so far apart.

\section{WHAT SHOULD BE DONE?}

As of the spring of 2006, the political atmosphere surrounding Iran's nuclear program is, at best, tense. The statements of Iranian President Mahmud Ahmadinejad

75. Conversations with an Iran expert (non-attribution principle applies) on the premises of Harvard University, May 10, 2005.

76. See in this regard Kenneth Pollack and Ray Takeyh, "Taking on Tehran," Foreign Affairs, Vol. 84, No. 2 (March/April 2005), p. 26.

77. See Kaveh Afrasiabi and Mustafa Kibaroglu, "Negotiating Iran's Nuclear Populism," Brown Journal of World Affairs, Vol. XII, No.1 (Summer/Fall 2005), pp. 255-268.

78. Hence, the incentives offered by the Bush Administration, such as providing Iran's aging major airliner (i.e., Iran Air) with spare parts are described as "peanuts" by Iran's Permanent Representative to the United Nations, Amb. Mohammad Javad Zarif, April 11, 2005, New York, in Afrasiabi and Kibaroglu, "Negotiating Iran's Nuclear Populism," p. 265. 
about Israel, Zionism, and Jews have exacerbated tension in the region. ${ }^{79}$ Prospects for finding a breakthrough to the standoff between Iran and the US as well as Israel are diminishing due to the unrelenting war of words. Therefore, any attempt to come up with meaningful proposals as to what should be done to resolve the differences among the parties may be considered as a futile effort. As discussed in the preceding section, non-diplomatic ways and means to prevent Iran from advancing its nuclear capabilities may prove ineffective and even destabilizing for the region. Hence, no matter how challenging they may be, non-military ways and means must be exploited to the utmost extent. With this objective in mind, the following is an account of what is indeed suggested by international experts, scholars, and intellectuals, including particularly the Iranians.

\section{REVIVING THE NWFZ/ME}

Naïve as it may seem at this stage, it is important to spend efforts to create a Nuclear-Weapons-Free Zone in the Middle East (NWFZ/ME). ${ }^{80}$ Hence, above all, the three-decade-old proposal tabled at the United Nations in 1974 to free the Middle East from nuclear weapons, and eventually from all weapons of mass destruction, should be given more serious thought. ${ }^{81}$ There have already been renewed attempts at governmental levels and in academic circles to achieve this goal. This requires a longterm perspective and the fulfillment of certain difficult conditions a priori, particularly the resolution of the Arab-Israeli conflict and the Palestine problem. Putting an end to the hostility between Iran and Israel, which has repercussions on the Palestine issue, is no less important.

The "Middle East Peace Process" between Palestine and Israel, if it proves successful against all the odds, may help considerably in defusing the tension in the region. If there is a breakthrough in this longstanding conflict it will have positive implications for the international efforts to stem the proliferation of weapons of mass destruction in the region. One of these positive implications could be the eventual normalization of relations between Israel and Iran; current hostility is a powerful incentive for Iran to embark on developing nuclear weapons.

With respect to the Middle East peace process, Iranian authorities have officially stated that the "two-state solution" - a Palestinian state side by side with Israel — would be acceptable to them. ${ }^{82}$ This might be an indirect way to recognize Israel's

79. President Ahmadinejad said, in a panel in Tehran on October 26, 2005, that "Zionism must be wiped off the map." He also denounced attempts to recognize Israel or to normalize relations with it.

80. See Mustafa Kibaroglu, "EURATOM \& ABACC: Safeguard Models for the Middle East?" in Jan Prawitz and James F. Leonard, eds., A Zone Free of Weapons of Mass Destruction in the Middle East (New York, Geneva: UNIDIR, 1996).

81. See Peter Jones, A Gulf WMD Free Zone within a Broader Gulf and Middle East Security Architecture (Dubai: Gulf Research Center, 2005).

82. Both the former Iranian President Ali Akbar Hashemi Rafsanjani, and the then Foreign Minister Kemal Kharazzi made statements to that effect during the two conferences in Tehran in March 2005. No policy change has been officially declared to date since Mahmud Ahmadinejad became Iran's new President. 
right to exist as a state, and a way to mitigate the Israeli fears stemming from perceived Iranian threats to their survival.

\section{A “GRAND BARGAIN" WITH THE US AND "SHOCK THERAPY" WITH ISRAEL}

On the issue of normalizing relations between Iran and Israel, Iranian senior analysts argue that "the formal recognition of the state of Israel by Iran may also be possible if essentially a 'grand bargain' can be achieved between the US and Iran." The "grand bargain" is further described:

in return for very big economic and political gains, Iran may agree both to shut down the enrichment facility as well as to take a very bold step regarding the formal recognition of Israel; the long-stalled relations between the two countries, which are virtually dead, may be revived only through shock therapy. If the US-Iran relations can be normalized as a result of a "grand bargain" through secret diplomacy, then Iran may officially declare that it will accept every UNSC resolution regarding the Middle East, which, among others, include the ones that refer to the creation of the state of Israel. ${ }^{83}$

This, in their view, "will constitute a direct way of recognition of Israel and its right to exist in the territories where it is created, and thus an important step in the normalization of bilateral relations. Eventually, establishment of diplomatic relations may also be possible."

Dr. Saideh Loitfian, from Tehran University, has clear suggestions for the "very big" gains:

Iran could enter into negotiations for shutting down its nuclear power industry, with the following conditions: all sanctions against Iran should be removed, particularly sanctions restricting investment in its oil and gas sectors; Iran should be admitted to the World Trade Organization (WTO); Iran should become a beneficiary of foreign technical aid to find substitute sources of electric power; and Iran should be given positive security guarantees to ensure its national security in the absence of its nuclear deterrence capability. Eventually Iran should be included in a regional security system in the Persian Gulf. ${ }^{84}$

\section{“Objective Guarantees” Proposed By Iran}

Taking into consideration the possibility that the parties fail to achieve a "grand bargain" or "shock therapy" paving the way ultimately to a nuclear-weapons-free

83. Conversations with senior analysts from Iran, who wished not to be identified, July 2005.

84. Authors' notes from the presentation of Dr. Saideh Loitfian during the working group sessions at the 55th Pugwash Conference in Hiroshima, Japan, July 25, 2005. 
Middle East, other proposals must be looked at carefully. Some Iranian officials and analysts maintain that, "Iran has neither the ambition to develop nuclear weapons nor the plans to destroy Israel;" they argue, "if Iran had such plans, it could have launched Shahab-3 missiles with chemical warheads and ranges up to $1,300 \mathrm{~km}$. These could easily have hit any city inside Israel causing massive destruction and casualties." 85 As an indication of their "good will" Iranian authorities proposed the "objective guarantees" to provide assurances that they will never produce nuclear weapons.

With these "objective guarantees," Iran's nuclear activities, including uranium enrichment, will remain peaceful under stringent inspection by the IAEA. Accordingly, Iran proposes "permanent placement of IAEA inspectors in Iran, whose job would be to monitor tightly the goings-on at various nuclear facilities such as Bushehr power plant and extensive use of tamper-proof seals put on Iran's centrifuges, as well as surveillance cameras." 86 Iranian officials say that they can agree to such stringent measures on inspections because they do not intend to build weapons, provided they are given firm security guarantees. These guarantees would include assistance in acquiring modern technology, and the normalization of economic transactions, meaning a lifting of the sanctions imposed by the US since the Islamic Revolution. ${ }^{87}$

The "objective guarantees" could constitute a basis for intense negotiations between Iran and the US, particularly if they included strong assurances that Iran would not be able to develop nuclear weapons clandestinely. Of course, there are risks associated with this proposal, no matter how sincere the Iranian authorities may be. There may be a change in Iran's policy, other than the rhetoric, under President Mahmud Ahmadinejad, and Iran may already have enriched weapons-grade uranium for several weapons. Another risk is the new Iranian President; regarding his dubious political career and the statements he made after becoming the President, some Americans are concerned that he may take the offer off the table. ${ }^{88}$ In that case, a hot confrontation may be inevitable. Should a confrontation between Iran and the US and/or Israel happen, then words like 'peace' and 'stability' may not make much sense when used in the context of Middle Eastern affairs for quite a long time.

One must bear in mind that peace in the Middle East can be achieved only with the concerted efforts of all the parties involved, both within and outside the region. Unilateral initiatives, by one or a few of the actors, in either direction, be it in the form of use or the threat of use of military force to subdue the other(s), or in the form of political/diplomatic demarches to mitigate the fears of the concerned parties, may not bring a just and lasting peace to the region. Thus, international regimes, among others, that aim to curb the proliferation of weapons of mass destruction must be

85. Conversations with senior analysts from Iran, who wished not to be identified, July 2005.

86. See Kaveh L. Afrasiabi, “The Peace Pipe's on the Table," Asia Times, March 1, 2005. Full text is available online at: http://www.atimes.com.

87. Conversations with Dr. Hossein Mousavian, Tehran, March 4, 2005.

88. See Brian Knowlton, “Some Held Hostage in '79 say Iran's Chief was a Captor," International Herald Tribune, July 1, 2005, p. 4. 
given the utmost support so as to make them effective everywhere in the world, particularly in the Middle East. For this to happen, however, the Israeli policy of relying on its undeclared nuclear arsenal as a deterrent must be reconsidered by Israeli policymakers. In light of the controversy over Iran's nuclear program, Israeli policymakers should consider whether the "nuclear option" still deters Israel's enemies.

It is no secret that Israel's nuclear capability, since its presumed inception in the early 1970s, has been the foremost incentive for the Arab world and Iran to embark upon developing their own "equalizers," which have taken the form of chemical or biological weapons programs and missile delivery systems as well as the clandestine attempts to develop nuclear weapons. ${ }^{89}$ Now, the Middle East is probably the most heavily armed region in the world. In addition, more recently, non-state actors (terrorist organizations) have proven how destructive attacks on their enemies could be. Nuclear or other sophisticated weapons systems may not be adequate anymore, to deter non-state actors. Even those who have relied on nuclear deterrence over the past decades are becoming more and more cautious about relying on the presence of nuclear weapons on their soil for the purposes of enhancing national security. ${ }^{90}$

A whole new generation of politicians, diplomats, military officers, strategists, scholars, and intellectuals are coming to decision-making posts, and replacing the older ones, everywhere in the world. One particular characteristic of many of them is their propensity to question and challenge established rules and regulations that have long been governing the international system, and which are, to a great extent, perceived as the legacy of the Cold War period. They are developing a new calculus of national security, which may at some point reject their country's longstanding liabilities in the face of the new structural changes and challenges in the world. Hence, there is a need for figuring out novel approaches that address the root causes of today's problems, which involve the new generation of decision makers as well, paving the way to the emergence of new regional and international structures that may make and effectively maintain international peace and stability.

89. See, for instance, Peter Herby, The Chemical Weapons Convention and Arms Control in the Middle East (Oslo: Peace Research Institute, 1992).

90. See Mustafa Kibaroglu, "Isn't it Time to Say Farewell to US Nukes in Turkey?" European Security, Vol. 14, No. 4 (2005), pp. 443-457. 